\title{
Application of Shumann and Joosten classification in fen peatland degradation stage assessment - A case study from southern Poland
}

\section{Bartlomiej Glina $^{1 *}$, Katarzyna Kołodziejczyk-Prażmo ${ }^{3}$, Adam Bogacz ${ }^{2}$, Klara Tomaszewska ${ }^{3}$, Zbigniew Kaczmarek ${ }^{1}$, Piotr Gajewskl ${ }^{1}$}

${ }^{1}$ Poznań University of Life Sciences, Department of Soil Sciences and Land Protection, Szydłowska 50, 60-656 Poznań, Poland

${ }^{2}$ Wrocław University of Life Sciences, Institute of Soil Science and Environmental Protection, Grunwaldzka 53, 50-375 Wrocław, Poland

${ }^{3}$ Wroclaw University of Environmental and Life Sciences, Department of Botany and Plant Ecology, pl. Grunwaldzki 24a, 50-363 Wrocław, Poland

*e-mail: glina@up.poznan.pl

Received: 26 May 2017 /Accepted: 23 October 2017

\begin{abstract}
The aim of this paper was to assess the degradation stage of fen peatland located in the north-western part of the Opolskie voivodeship in accordance with "peatland degradation stages" classification. Understanding of the current state of peatland will be helpful in the future management and possible restoration. Field survey including vegetation and soil research were carried out in May 2013, soil material for laboratory analysis were collected by using "Instorf" peat sampler from four sampling points. Obtained results allowed to classify the study area (located within a larger peatland complex along the Prosna river valley) to minor stage of degradation, with spontaneous changes in vegetation community and soil cover. Only few species of plants typical for fen peatlands were recorded. Moreover, soil cover research did not confirm mursh forming process, typical for strongly degraded peatland areas. Obtained results may indicate that possible future restoration will bring the expected effect. It is very likely, that fen peatland vegetation will regenerate spontaneously, provided that diaspores of the key peat-forming plant species are available in the soil.
\end{abstract}

Key words: organic soils, peat-forming plants, physical properties, secondary transformation.

\section{Introduction}

Essential for understanding the functions of peatland is the awareness that in this ecosystem three main components (plants, water and soil) are very closely connected and interdependent (Schumann \& Joosten, 2008). The plants determine the type of formed peat and its hydraulic properties (Nichols \& Boelter, 1984). The hydrological conditions determines plants grow (Kotowski \& Van Diggelen, 2004) and peat decomposition (Prévost et al.,
1999), whereas peat structure and the relief determine how the water flows and fluctuates in the peat soils (Bullock \& Acreman, 2003). Mentioned close interrelations entail that when any one of these components changes, the others will change too (Schumann \& Joosten, 2008). Degradation on peatlands are likely to be mediated through changes in hydrology, direct and indirect effects of temperature, as well as management type (Ferrati et al., 2005). Over the past decades, changes in peatlands hydrology and ecology has grown considerably (Erwin, 2009). In most cas- 
es this phenomenon is the effect of strong human impact such as drainage, peat extraction (Tuukkanen et al., 2014), forestry (Glina et al., 2016b) or agricultural use of peatlands (Limpens et al., 2008; Glina et al., 2016a). In the Middle and Western Europe, up to $90 \%$ of natural peatlands were strongly influenced by human impact during the last century. Especially, after Second World War peatlands have been drained and converted into managed agro-ecosystems (Heller \& Zeitz, 2012). Degraded or damaged peatland since late 20th centuries have become the focus of restoration management (Parry et al., 2014). However, before application of restoration treatments, an multidirectional assessment of peatlands concerning both, soil, hydrology and phytosociology is required. Classification of peatland degradation stages (Table 1), proposed by Shumann and Joosten (2008) in manual Global Peatland Restoration is an excellent tool for degradation degree assessment, which was formerly used in degradation assessment of peatlands

Table 1. Peatland degradation stages (after Schumann \& Joosten, 2008; modified)

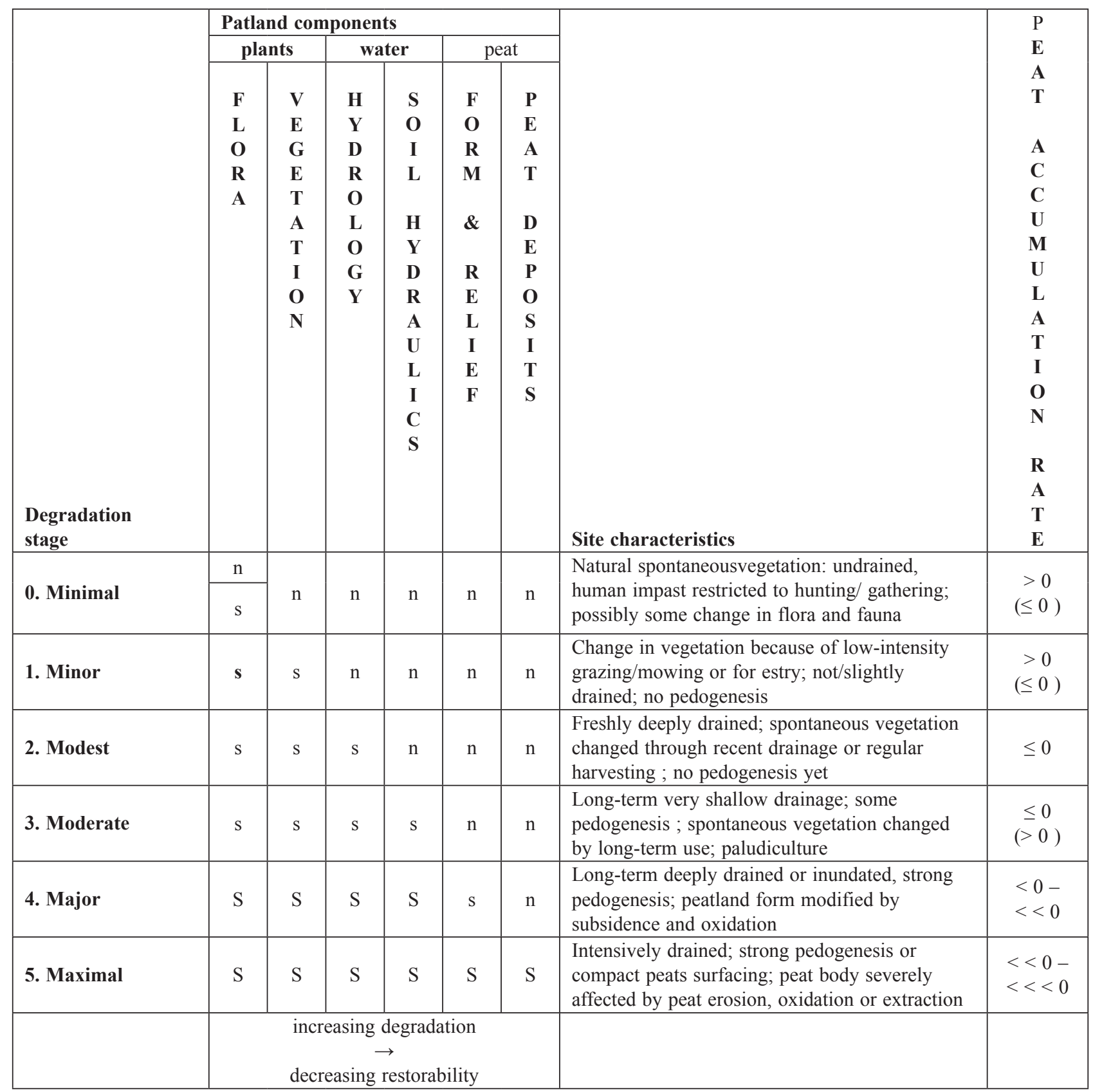

Explanations: $\mathrm{n}-$ not $-; \mathrm{s}-$ slighty $-; \mathrm{S}-$ Severely afected 
in the Biebrza valley, for example (Shumann \& Joosten, 2008). Discussed classification assumed six degradation stages, from minimal (stage 0) to maximal (stage 5). Based on field observation and laboratory analysis of each of the peatland components, it is possible to assign study area to proper degradation stage.

The main objective of this paper was to assess the degradation stage of fen peatland in the Borek village in accordance with ,peatlands degradation stages" classification. Understanding the current state of peatland (before peat extraction) will be helpful in the future management and possible restoration.

\section{Material and methods}

\subsection{Study area}

Study peatland is located near the Borek village in the north-western part of the opolskie province (Fig. 1A), in the valley of Prosna river, ca. 250 meters south from the riverbed (Kołodziejczyk, 2013). The study site (ca. 0.082 ha) was set in a part of a larger peatland complex located along the Prosna river valley, between Praszka and Bezula villages (PIG, 1994). In terms of geographic regionalization (Kondracki, 2011), the study area is located in the north-western part of Silesian Highland. The peat deposits near the Borek village are of Holocene origin, consisted of Carex sp. remains (e.g. C. rostrata, C. elongata, C. elata) in particular, with addition of Bryales sp. and Betula wood fragments (Kołodziejczyk, 2013). The peat thickness within the study site ranges from 1.2 to 2.5 meters. The mean annual air temperature range here from 5 to $15^{\circ} \mathrm{C}$ in the years $2006-2012$. The coldest month is January $\left(-2.5^{\circ} \mathrm{C}\right)$, while the hottest is July $\left(18.5^{\circ} \mathrm{C}\right)$. The mean annual precipitation varied in the range of 600 to $650 \mathrm{~mm}$. The growing period begins in the second decade of March and amounts to 220 days (Kołodziejczyk, 2013).

Described part of peatland is operated by ,,Torf Corporation" company, as a source of peat for cosmetics production (Glina, 2016). Study area as shown in the Figure 1B is divided into two parts. The water reservoir, visible on the right is the effect of actual surface peat mining from openpit using heavy machinery (excavators). Whereas on the left -4 sampling points are marked (Fig. 1B). This part of peatland will be used in the close future as a source of peat.

\subsection{Field survey and sampling}

Field survey including vegetation and soil research were carried out in May 2013 within the area of study fen peatland. Soil material for laboratory analysis were collected by using „Instorf” peat sampler as peat cores (50 cm long, $5.2 \mathrm{~cm}$ diameter) from four sampling points (Fig. 1B). Additionally undisturbed subsamples $\left(5 \mathrm{~cm}^{3}\right)$ for bulk density determination using drying-weight method (Chambers et al., 2011) were sampled. Soil samples were sampled by genetic soil horizons in three replications (in total 99 samples). During phytosociological surveys 2 relevés $\left(5 \mathrm{~m}^{2}\right.$ each) were taken according to the method by Braun-Blanquet (1951) in the same places from which the soil material

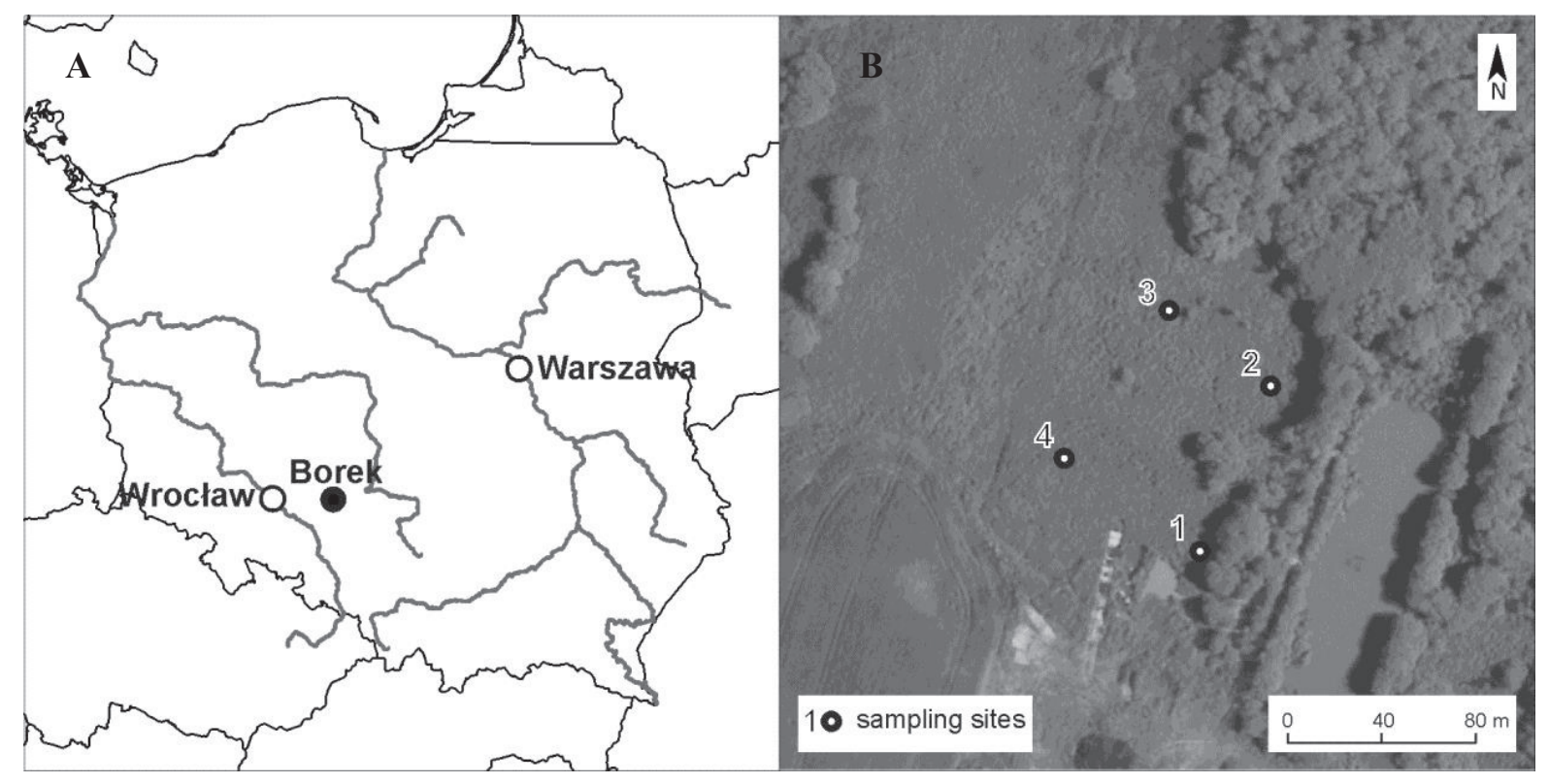

Figure 1. Location of Borek village (A) and sampling sites within study peatland (B) (source of map: http://geoportal.gov.pl) 
was sampled, the plants name follows Mirek et al. (2002). Following the study by Matuszkiewicz (2008), identified plant species were assigned to a particular phytosociological class and existing phytocenosis were determined as well. Additionally during field works the groundwater level at each sampling site were measured.

\subsection{Laboratory analysis}

In the laboratory, soil samples (exept undisturbed samples) were dried at $105^{\circ} \mathrm{C}$, mixed and plant remains were removed meticulously. Ash content was measured by burning soil samples (dried at $105^{\circ} \mathrm{C}$ to constant weight) in a muffle furnace at $550^{\circ} \mathrm{C}$ for $5 \mathrm{~h}$ (Bojko \& Kabala, 2014). The soil bulk density, based on $5 \mathrm{~cm}^{3}$ subsamples, was measured using a drying-weighing method (Chambers et al., 2011). For pH measurement, suspensions were prepared using dry peat and distilled water at the ratio 1:2.5 (Kabala et al., 2016). Total organic carbon (TOC) and total nitrogen (TN) for calculate TOC/TN ratio were determined using a Vario-
Max elemental analyzer. State of secondary transformation of the studied soils was estimated by water-holding capacity index $\mathrm{W}_{1}$ (Gawlik, 2000).

\section{Results and discussion}

\subsection{Vegatation composition and water level}

Total number of identified plant species within the study area amounted 20 (Table 2). Recorded species belong to 5 phytosociological classes: Molinio-Arrhenatheretea, Phragmitetea, Artemisietea vulgaris, Alnetea glutinosae and Scheuchzerio-Caricetea nigrae. The most of them (40\%) being representatives of Molinio-Arrhenatheretea and Phragmitetea class (35\%) (Table 2, Fig. 2). The presence of species are characteristic of grasslands communities occurring on organic substrate, such as Cirsium palustre (L.) Scop., Filipendula ulmaria L. (Maxim), Geranium palustre L., Lysimachia vulgaris L., Lythrum sali-

Table 2. Species identified in the study area, their membership in phytosociological classes and share in Caricetum paniculatae community (in scale of Braun-Blanquet, 1951)

\begin{tabular}{|c|c|c|c|c|}
\hline \multirow{3}{*}{ List of species } & \multirow{3}{*}{ Classes } & \multirow{3}{*}{ Family } & \multirow{2}{*}{\multicolumn{2}{|c|}{$\begin{array}{c}\text { Caricetum paniculatae } \\
\text { community }\end{array}$}} \\
\hline & & & & \\
\hline & & & 1 & 2 \\
\hline Calamagrostis stricta (Timm) Koeler & Scheu.-Car. Nigrae & Poaceae & + & \\
\hline Calystegia sepium (L.) R. Br. & Artem. & Convolvulaceae & 1 & 1 \\
\hline Carex gracilis Curtis & Phr. & Cyperaceae & 2 & 1 \\
\hline Carex paniculata $\mathrm{L}$. & Phr. & Cyperaceae & 5 & 5 \\
\hline Carex pseudocyperus L. & Phr. & Cyperaceae & + & \\
\hline Cirsium palustre (L.) Scop. & Mol.-Arrh. & Asteraceae & + & \\
\hline Eqiusetum fluviatile L. & Phr. & Equisetaceae & + & + \\
\hline Filipendula ulmaria L. (Maxim.) & Mol.-Arrh. & Rosaceae & 1 & 2 \\
\hline Geranium palustre L. & Mol.-Arrh. & Geraniaceae & + & + \\
\hline Iris pseudacorus L. & Phr. & Iridaceae & + & \\
\hline Lycopus europaeus $\mathrm{L}$. & Aln. glu. & Lamiaceae & & + \\
\hline Lysimachia vulgaris L. & Mol.-Arrh. & Primulaceae & 1 & 2 \\
\hline Lythrum salicaria $\mathrm{L}$. & Mol.-Arrh. & Lythraceae & 1 & 1 \\
\hline Peucedanum palustre (L.) Moench & Phr. & Apiaceae & 1 & 2 \\
\hline Poa palustris L. & Mol.-Arrh. & Poaceae & + & + \\
\hline Scutelaria galericulata $\mathrm{L}$. & Phr. & Lamiaceae & & + \\
\hline Solanum dulcamara $\mathrm{L}$. & Aln. glut. & Solanaceae & + & \\
\hline Urtica dioica $\mathrm{L}$. & Artem. & Urticaceae & 1 & 2 \\
\hline Veronica longifolia $\mathrm{L}$. & Mol.-Arrh. & Scrophulariaceae & 1 & + \\
\hline Vicia cracca $\mathrm{L}$. & Mol.-Arrh. & Fabaceae & & + \\
\hline Total: 20 species & & & & \\
\hline
\end{tabular}

Symbols of classes: Scheu-Car. nigrae - Scheuchzerio-Caricetea nigrae, Aln-glut - Alnetea glutinosae, Mol-Arrh - Molinio-Arrhenatheretea, Artem - Artemisietea vulgatis, Phr - Phragmitetea 
caria L. Veronica longifolia L., Vicia cracca L. (MolinioArrhenatheretea class), and characteristic of the rushes communities (All. Magnocaricion), such as Carex gracilis Curtis, Carex paniculata L., Carex pseudocyperus L., Eqiusetum fluviatile L., Iris pseudacorus L., Peucedanum palustre (L.) Moench, Scutelaria galericulata L. (Phragmitetea class) (Matuszkiewicz, 2008). Generally, within the study part of the peatland, were detected merely 8 species originating from classes typical for fen peatlands: 7 species from Phragmitetea class (Carex gracilis Curtis, Carex paniculata L., Carex pseudocyperus L., Eqiusetum fluviatile L., Iris pseudacorus L., Peucedanum palustre (L.) Moench, Scutelaria galericulata L.) and only 1 species from Scheuchzerio-Caricetea nigrae class (Calamagrostis stricta (Timm) Koeler) (Table 2). The analysis of plant species showed, that they are also included in 16 botanical families. Most of them belongs to Cyperaceae family (3 species) and Poaceae family (2 species) (Table 2). Presence of Urtica dioica, Lysimachia vulgaris and Cirsium palustre may indicate slight degradation of Caricetum paniculatae community, what was reported by (Matuszkiewicz, 2008; Wołejko, 2013).

Described peatland is supplying in water by seepages of ground water, which interflow via sandy and loamy sediments. Moreover, it is periodically flooded by Prosna river, thus it can be classified to fluviogenic-soligenic peatland type. Fen peatlands fed with flood or ground water are frequent in the Polish lowlands (e.g. Kalisz et al., 2010; Forysiak et al., 2014; Glina et al., 2016a). In the sampling time the water level within study sites 1 and 2 was $10-15 \mathrm{~cm}$ below the ground level, whereas sites 3 and 4 were slightly flooded - the water level was $5 \mathrm{~cm}$ above the ground level.
Observed high water level, thus soil saturation may allowed for the continuous peat accumulation process, what was reported by Prévost et al. (1999). We found out, that the open-pit located in the right part of the study area, did not affect the hydrological conditions on site. We assume that, it is the result of weak drainage and little peat extraction. In general, peat extraction sites are strongly drained (deep drainage ditches), what was reported in multiple papers (e.g. Farrell \& Doyle, 2003; McCarter \& Price, 2013).

\subsection{Soil description and selected properties}

In accordance with Polish Soil Classification (PSC, 2011) investigated soil profiles 1 and 2 were classified as typical hemic peat soils (in Polish: gleba torfowa hemowa typowa), soil profile 3 - sapric-hemic peat soil (in Polish: gleba torfowa saprowa-hemowa) and profile 4 as typical sapric peat soil (in Polish: gleba torfowa saprowa typowa). In the case of the FAO-WRB classification (IUSS Working Group WRB, 2015) studied soils belonged to Sapric or Hemic Histosols (Table 3). Ash content varied within a wide range 9.11 to $72.2 \%$. The smallest amounts of mineral material admixtures were observed in endopedons, while in the surface soil horizons its content was even 5 to 7 fold higher. Increase of mineral material contribution in the surface organic horizons might be the result of periodic flooding of Prosna river, what was also reported by Glina (2016). In the layers with the highest admixture of mineral particles (sand mainly) also the bulk density values were high (Table 3 ). Recorded soil $\mathrm{pH}$ were typical for minerothrophic peat soils (Sjörs \& Gunnarson, 2002) and ranged between 5.1 to 5.9 (Table 3 ). Among investigated soils only in the hemic

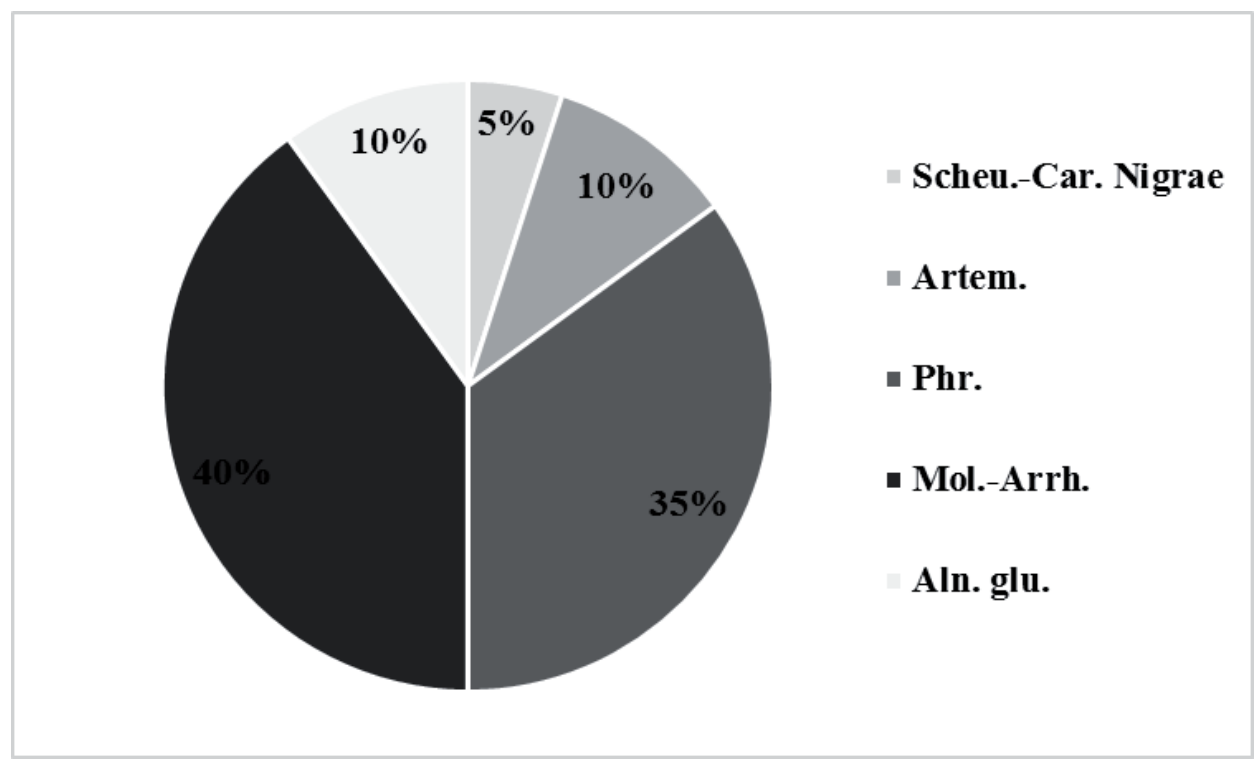

Figure 2. Percentage share of phytosociological classes within the study peatland (symbols the same as in Table 2) 
peat soils (profiles 1 and 2) the increase of $\mathrm{pH}$ with soil depth was observed. The minerogenic character of study peatland was confirmed by high values of cation exchange capacity (CECe) and base saturation (BS). Mean values of these soil parameters varied from 24.4 to $62.1 \mathrm{cmol}(+)$ $\mathrm{kg}^{-1}$ and 91.1 to $97.4 \%$, respectively (Table 3 ). Worth to note is the great predominance of base over acid cations, demonstrated by high BS over $90 \%$ in the study organic soils. High BS along with low $\mathrm{pH}$ in the examined soils, seem surprising. However, in minerogenic organic soils observed situation is quite common (e.g. Glina et al., 2013; Mendyk et al., 2013; Jonczak, 2015). It could be explained as a result of soil buffering properties and weak reagent $(1 \mathrm{M} \mathrm{KCl})$ used for extraction of exchangeable acid cations. The calculated TOC/TN ratio (indicator for the mineralisation of organic matter) contained in a narrow ranged from 14.4 to 20.1. Observed TOC/TN ratio below 20, indicated the temporary drying of organic soils, what accelerates the mineralisation of organic matter (Glina et al., 2016a, b). However the mineralisation process is rather weak, what

Table 3. Selected properties of study organic soils (mean values)

\begin{tabular}{|c|c|c|c|c|c|c|c|c|c|}
\hline $\begin{array}{c}\text { Soil } \\
\text { horizon }\end{array}$ & $\begin{array}{l}\text { Depth } \\
\text { (cm) }\end{array}$ & $\begin{array}{l}\text { Ash } \\
(\%)\end{array}$ & $\begin{array}{c}\text { BD } \\
(\mathrm{g} \cdot \mathrm{cm}-3)\end{array}$ & & $\begin{array}{l}\mathrm{W}_{1} \\
\text { index }\end{array}$ & $\begin{array}{c}\text { pH } \\
\mathrm{H}_{2} \mathrm{O}\end{array}$ & $\begin{array}{c}\text { TOC/ } \\
\text { TN }\end{array}$ & $\begin{array}{c}\text { CECe } \\
\text { cmol(+)kg-1 }\end{array}$ & $\begin{array}{l}\text { BS } \\
\%\end{array}$ \\
\hline \multicolumn{10}{|c|}{$\begin{array}{l}\text { Profile } 1 \text { - gleba torfowa hemowa typowa (PSC, 2011) } \\
\text { Sapric Hemic Histosol (Dystric) (WRB, 2015) }\end{array}$} \\
\hline Oa1 & $0-20$ & 37.6 & 0.34 & 0.43 & initial & 5.1 & 14.4 & 62.1 & 96.5 \\
\hline $\mathrm{Oa} 2$ & $20-30$ & 17.3 & 0.22 & 0.32 & none & 5.2 & 14.7 & 40.3 & 96.0 \\
\hline Oe1 & $30-57$ & 12.2 & 0.15 & 0.32 & none & 5.3 & 16.7 & 45.1 & 96.0 \\
\hline Oa3 & $57-65$ & 10.9 & 0.12 & 0.33 & none & 5.5 & 18.0 & 48.8 & 95.9 \\
\hline Oe 2 & $65-78$ & 9.11 & 0.16 & 0.49 & none & 5.5 & 18.6 & 48.6 & 95.1 \\
\hline Oe3 & $78-100$ & 9.22 & 0.19 & 0.48 & none & 5.7 & 18.7 & 41.8 & 95.7 \\
\hline \multicolumn{10}{|c|}{$\begin{array}{c}\text { Profile } 2 \text { - gleba torfowa hemowa typowa (PSC, 2011) } \\
\text { Sapric Hemic Histosol (Eutric) (WRB, 2015) }\end{array}$} \\
\hline Oa1 & $0-20$ & 51.0 & 0.45 & 0.19 & none & 5.3 & 15.7 & 29.1 & 91.1 \\
\hline $\mathrm{Oa} 2$ & $20-27$ & 36.6 & 0.34 & 0.24 & none & 5.2 & 15.5 & 26.2 & 92.4 \\
\hline Oe1 & $27-43$ & 14.1 & 0.15 & 0.24 & none & 5.2 & 17.1 & 63.3 & 97.8 \\
\hline Oa3 & $43-50$ & 15.7 & 0.21 & 0.31 & none & 5.6 & 19.6 & 68.6 & 97.4 \\
\hline Oe2 & $50-77$ & 10.7 & 0.13 & 0.36 & none & 5.5 & 20.1 & 47.9 & 97.1 \\
\hline Oe3 & $77-100$ & 12.4 & 0.18 & 0.23 & none & 5.7 & 19.4 & 46.7 & 96.6 \\
\hline \multicolumn{10}{|c|}{$\begin{array}{l}\text { Profile 3: gleba torfowa saprowo-hemowa typowa (PSC, 2011) } \\
\text { Hemic Sapric Histosol (Eutric) (WRB, 2015) }\end{array}$} \\
\hline Oa1 & 0-17 & 50.2 & 0.36 & 0.21 & none & 5.5 & 15.2 & 46.4 & 95.7 \\
\hline $\mathrm{Oa} 2$ & $17-30$ & 36.5 & 0.24 & 0.62 & weak & 5.5 & 16.2 & 34.0 & 92.3 \\
\hline $\mathrm{Oa} 3$ & $30-56$ & 18.5 & 0.17 & 0.51 & weak & 5.2 & 18.4 & 56.2 & 97.2 \\
\hline $\mathrm{Oa} 4$ & 56-67 & 19.6 & 0.22 & 0.30 & none & 5.3 & 18.0 & 43.5 & 96.3 \\
\hline Oe1 & $67-88$ & 9.60 & 0.11 & 0.31 & none & 5.6 & 19.1 & 42.7 & 95.3 \\
\hline Oe2 & $88-100$ & 12.4 & 0.19 & 0.23 & none & 5.5 & 19.4 & 46.8 & 96.2 \\
\hline \multicolumn{10}{|c|}{$\begin{array}{c}\text { Profile } 4 \text { : gleba torfowa saprowa typowa (PSC, 2011) } \\
\text { Sapric Histosol (Orthoeutric) (WRB, 2015) }\end{array}$} \\
\hline Oa1 & $0-10$ & 72.2 & 0.58 & 0.63 & weak & 5.9 & 12.3 & 44.2 & 96.4 \\
\hline $\mathrm{Oa} 2$ & $10-22$ & 71.4 & 0.60 & 0.67 & medium & 5.8 & 13.8 & 24.2 & 91.7 \\
\hline Oa3 & $22-56$ & 18.1 & 0.26 & 0.36 & none & 5.7 & 17.4 & 51.1 & 96.5 \\
\hline $\mathrm{Oa} 4$ & $56-70$ & 19.0 & 0.17 & 0.33 & none & 5.8 & 17.2 & 57.4 & 97.2 \\
\hline Oa5 & $70-100$ & 17.2 & 0.28 & 0.27 & none & 5.9 & 19.4 & 50.1 & 97.2 \\
\hline
\end{tabular}

Explanations: BD - bulk denisty, $\mathrm{W}_{1}$ - state of secondary transformation, $\mathrm{CECe}$ - cation exchange capacity, BS - base saturation 
was confirmed by low $\mathrm{W}_{1}$ index values. We found that surface soil horizons were under initial or weak secondary transformation process, in particular (Table 3). The lowest values of TOC/TN ratio were recorded in the horizons with the highest values of $\mathrm{W}_{1}$ index. Such dependency were also reported in relation to other human-affected lowland fen peatlands in Poland (e.g. Kalisz et al., 2010, 2015; Glina et al., 2016a, b).

\subsection{Degradation stage assessment}

Based on above described results of vegetation, soil and water investigation, an assessment of degradation stage was done. In accordance to Shumann and Joosten classification (2008) examined part of peatland was classified to minor stage of degradation. Presence of few peat-forming plant species (e.g. Carex gracilis, Carex paniculata, Carex pseudocyperus or Eqiusetum fluviatile), typical for minerotrophic fen peatlands, might indicate slight changes in original plant communities vegetation. Inconsiderable defragmentation of vegetation cover is often reported as fundamental indicator for initial transformation of peatland ecosystems (Kotowski \& Van Diggelen, 2004). Moreover, minor stage of peatland degradation stays together with soil cover investigation results. The uppermost soil organic horizons were mostly under weak of initial secondary transformation process $\left(\mathrm{W}_{1}\right.$ index $)$. It may be the effect of high ground water level on site (Ferrati et al., 2005). Furthermore, lack of drainage ditches along the study area is another factor that determines good hydrological conditions. Strong secondary transformation (mursh forming process), typical for strongly drained peatland areas (Kalisz et al., 2010, 2015; Glina et al., 2016b), was not confirmed in our study. Obtained results may indicate that possible future restoration will gain the expected positive effect. It is very likely, that fen peatland vegetation will regenerate spontaneously, provided that diaspores of the key peat-forming plant species are available in the soil. This consideration is supported by the results published by Kołodziejczyk (2013), who reported great amount of seed and spores of peat-forming plants in the soils from Borek peatland.

\section{Conclusions}

The following conclusions can be drawn from the results of fen peatland analysis and the comparisons presented in this paper:

1. „Peatland degradation stages" classification proposed by Schumann and Joosten is a good and easy to use tool in peatland assessment, however requires detailed analysis of all of the three main components (vegetation, water and soil).
2. The current floristic composition on the study part of the Borek peatland, indicated slightly degradation of sedge marsh (Caricetum paniculatae community).

3. Topsoil horizons of organic soils are under initial or weak secondary transformation process resulted from natural fluctuation of groundwater level - not affected by drainage.

4. Minor stage of Borek peatland degradation indicated that possible future restoration will gain the expected positive effect, easily.

\section{References}

Braun-Blanquet J., 1951, Pflanzensoziologie, 2 Aufl., Springer-Verlag, Wien.

Bojko O. \& Kabala C., 2014, Loss-on-ignition as an estimate of total organic carbon in mountain soils, Polish Journal of Soil Science 47(2): 71-79.

Bullock A. \& Acreman M., 2003, The role of wetlands in the hydrological cycle, Hydrology and Earth System Sciences 7: 358-389.

Chambers F.M., Beilman D.W. \& Yu Z., 2011, Methods for determining peat humification and for quantifying peat bulk density, organic matter and carbon content for palaeostudies of climate and peatland carbon dynamics, Mires and Peat 7: 1-10.

Erwin K.L., 2009, Wetlands and global change: the role of wetland restoration in a changing world, Wetlands Ecology and Management 17: 71-84.

Farrell C.A., \& Doyle G.J., 2003, Rehabilitation of industrial cutaway Atlantic blanket bog in County Mayo, North-West Ireland, Wetlands Ecology and Management 11: 21-35.

Ferrati R., Canziani G.A. \& Moreno D.R., 2005, Estero del Ibera: hydrometeorological and hydrological characterization, Ecological Modelling 186: 3-15.

Forysiak J., Kloss M., Obremska M., Żurek S., 2014, Lateglacial and Holocene sediments of some valley peatlands in the Łódź region in relation to palaeoenvironmental changes, Folia Quaternaria 82: 5-30.

Gawlik J., 2000, Division of differently silted peat formations into classes according to their state of secondary transformations, Acta Agrophysica 26: 17-24.

Glina B., Bogacz A., Bojko O., Kordyjarek M., 2013, Diversity of soils in the peatland located on slope near Karłów (Stołowe Mountains National Park), Episteme 18(3): 287-296.

Glina B., 2016, Selected trace elements concentrations in peat used for cosmetic production - A case study from southern Poland, Civil and Environmental Engineering Reports 23(4): 51-60.

Glina B., Gajewski P., Kaczmarek Z., Owczarzak W. \& Rybczyński P., 2016a, Current state of peatland soils 
as an effect of long-term drainage - preliminary results of peatland ecosystems investigations in the Grójecka Valley (central Poland), Soil Science Annual 67(1): 3-9.

Glina B., Bogacz A., Gulyás M., Zawieja B., Gajewski P. \& Kaczmarek Z., 2016b, The effect of long-term forestry drainage on the current state of peatland soils: A case study from the Central Sudetes, SW Poland, Mires and Peat 18(21): 1-11.

Heller C. \& Zeitz J., 2012, Stability of soil organic matter in two northeastern Germany fen soils: the influence of site and soil development, Journal of Soil and Sediments 12: 1231-1240.

IUSS Working Group WRB., 2015, World reference base for soil resources. International Soil Classification System for Naming Soil and Creating Legends for Soil Maps, Food and Agriculture Organization of the United Nations, Rome.

Jonczak J., 2015. Buffering properties of the soils developed from mill-pond deposits in the valley of the Jarosławianka Creek, Journal of Ecology and Protection of the Coastline 19: 37-48.

Kabala C., Musztyfaga E., Gałka B., Labuńska D. \& Manczyńska P., 2016, Conversion of soil pH 1:2.5 KCl and 1:2.5 $\mathrm{H}_{2} \mathrm{O}$ to $1: 5 \mathrm{H}_{2} \mathrm{O}$ - conclusions for soil management, environmental monitoring and international soil databases, Polish Journal of Environmental Studies 25(3): 647-653.

Kalisz B., Łachacz A. \& Głażewski R., 2010, Transformation of some organic matter components in organic soils exposed to drainage, Turkish Journal of Agriculture and Forestry 34: 245-256.

Kalisz B., Łachacz A. \& Głażewski R., 2015, Effects of peat drainage on labile organic carbon and water repellency in NE Poland, Turkish Journal of Agriculture and Forestry 39: 20-27.

Kołodziejczyk K., 2013, Plant macroremains analysis as the basis for assessing degradation of peatlands used in agriculture, $\mathrm{PhD}$ thesis, Wrocław Univeristy of Life Sciences.

Kondracki J., 2011, Geografia regionalna Polski [Regional geography of Poland], Wyd. Naukowe PWN, Warszawa.

Kotowski W. \& Van Diggelen R., 2004, Light as an environmental filter in fen vegetation, Journal of Vegetation Sciences 15: 583-594.

Matuszkiewicz W., 2008, Przewodnik do oznaczania zbiorowisk roślinnych Polski [A guide for identification of plant communities in Poland], Wyd. Naukowe PWN, Warszawa.

McCarter C.P.R., \& Price J.S., 2013, The hydrology of the Bois-de-Bel bog peatland restoration: 10 years post restoration, Ecological Engineering 55: 73-81.

Mendyk Ł., Markiewicz M., Świtoniak M. \& Bednarek R., 2013, The use of orthophoto map for soils mapping of dwindling lakes catchment areas: a case study of Sumowskie Lake, NE Poland, Ecological Questions 17: 57-66.

Mirek Z., Piękoś-Mirkowa H., Zając A. \& Zając M., 2002, Flowering plants and Pteridophytes of Poland. A Checklist. Szafer Institute of Botany, Polish Academy of Sciences, Kraków.

Nichols D.S. \& Boelter D.H., 1984, Fiber size distribution, bulk density, and ash content of peats in Minnesota, Wisconsin and Michigan, Soil Science Society of American Journal 48: 1320-1328.

PSC, Polish Soil Classification (Systematyka gleb Polski), 2011, Roczniki Gleboznawcze - Soil Science Annual 62(3): 1-193.

PIG, Państwowy Instytut Geologiczny, 1994, Objaśnienie do szczegółowej Mapy Geologicznej Polski 1:50000 [Polish Geological Institute, 1994, Explanation to detailed Geological Map of Poland 1:50000], Warszawa.

Parry L.E., Holden J. \& Chapman P.J., 2014, Restoration of blanket peatlands, Journal of Environmental Management 133: 193-205.

Prévost M., Plamondon A. P. \& Belleau P., 1999, Effects of drainage of a forested peatland on Water quality and quantity, Journal of Hydrology 214: 130-143.

Schumann M. \& Joosten H., 2008, Global Peatland Restoration Manual, Institute of Botany and Landscape Ecology, Greifswald University, Germany.

Sjörs H. \& Gunnarson U., 2002, Calcium and pH in north and central Swedish mires water, Journal of Ecology 90: 650-657.

Tuukkanen T., Martilla H. \& Klove B., 2014, Effect of soil properties on peat erosion and suspended sediment delivery in drained peatlands, Water Resources Research 50(4): 3523-3535.

Wołejko L., 2000, Roślinność szuwarowa i turzycowiskowa z klasy Phragmitetea kompleksów źródliskowych Polski północno-zachodniej [Rush and sedge vegetation from the class Phragmitetea in seepage areas of NorthWestern Poland], Folia Universitatis Agriculturae Stetinensis, Agricultura 85: 221-245. 